\title{
Bionetworking over DNA and biosocial interfaces: Connecting policy and design
}

\author{
DENISA KERA ${ }^{1}$
}

\begin{abstract}
Personal genetic information services (PGI) or direct-to-consumer genomics (DTC) presents a convergence of web 2.0 platforms with consumer-oriented genetics that brings together issues of policy and design. The rise of networking over DNA profile and biodata (bionetworking) challenges the common design and HCI notions of interaction, social networking and user needs. It confronts design thinking and HCI with various biopolitical and biosocial issues discussed in STS studies. These interfaces intensify the troubled relationship between what is social and biological, collective and individual, public and private, natural and political, material (embodied) and based on data or discourses. At the same time, this fast evolving convergence of biosciences with social networking transforms scientific practices in a way which demonstrates the importance of design in discussing issues of STS and policy. The notion of cosmopolitics as "collective experimentation" and "progressive composition of the common world" (Bruno Latour) offers a framework for understanding this connection between philosophy, policy and design. Bionetworking interfaces in this sense serve as probes for testing future collectives which transform the notions of human subjects, community and politics.
\end{abstract}

\section{Introduction}

Eugenics-style dating based on DNA profiles with GenePartner", 2 , large matriarchal families created by sharing data on donors' sperm with Donor Sibling Registry ${ }^{3}$, genealogical 'tribes' and biotech enthusiasts discussing their DNA makeup on 23 and $\mathrm{Me}^{4}$, crowdsourced clinical trials involving self-monitoring and sharing DNA data in projects such as "Quantified Selves", and DIYgenomics ${ }^{6}$ - all these represent various forms of bionetworking services existing today. Bionetworking combines genetic testing with cloud computing and web 2.0 services, and enables interaction and networking around single-nucleotide polymorphisms (SNPs) and other components of our individual genome.

While social networking via Facebook, Myspace or LinkedIn revolves around profiles that users create themselves, by indicating their personal history, interests and social and geographical context, bionetworking services rely on biological profiles generated in science laboratories. Data related to carrier, presymptomatic, diagnostic, genealogical and other forms of DNA testing ${ }^{7}$ are the basis on which strangers interact with each other, build communities and carry out various citizen science projects. The individuals involved in these networks initiate personal relationships based on scientific data and research practices. For example, 'families' coalesce around genealogical research on haplogroups, haplotypes and donors' data, and whole communities could be created based on their members' interest in following a particular gene and its interaction with the environment, diet, lifestyle etc. ${ }^{8}$

DNA sequences, SNPs which define the variations between members of the same species, and databases of donors' sperms, defined by numbers and other biological 
data, are becoming the basis of certain kinds of online interaction. This interaction is often serendipitous rather than planned, and relies on expert knowledge and laboratory results rather than the free choices of the individual or some form of social pressure. Interaction based on DNA profiles and biodata follows a trend in social networking and mobile interaction that involves casual and random connections between strangers ${ }^{9}$, and various forms of crowdsourcing and participatory design strategies ${ }^{10}$. The importance of chance and the figure of the stranger as an object of interaction harks back to Stanley Milgram's ethnography of urban culture ${ }^{11}$ and Erving Goffman's concept of "chance-taking" 12 as an attribute of modern living and society. Such chance encounters represent unexpected patterns and connections that define a hidden (networked) logic in modern cities that we can use to our advantage by developing interfaces to increase the visibility of these emergent patterns. One example of such "designed" emergence is the growth of crowdsourcing services, such as Amazon's "Mechanical Turk", and the micro-tasks strategies that allow the rapid collection of user measurements and user testing ${ }^{13}$, as well as collective collaboration, problem solving and decision-making based on "commons-based peer production"14 and participatory design. ${ }^{15}$

The ubiquitous, distributed and fragmented interactions over bits of data and microtasks support current research needs in epigenetics, metagenomics and nutrigenomics studies. Bionetworking, based on such crowdsourcing and participatory strategies, supports this more integrated approach to personal genomics by motivating users to follow, share and compare their daily routines and to monitor the environmental factors which influence their genome. The services emphasise the serendipity behind interactions based on DNA profiles, as well as the crowdsourcing experience of providing data for some form of public good related to bioscience.

However, the use of DNA data as a basis for (bio)networking and crowdsourcing poses many urgent questions. How will the availability of DNA data over different platforms and interfaces change our understanding of human subjects, community, user needs and web services? What are the implications of designs that depend on certain form of biological reductionism and on data that have questionable validity and utility? What are the implications of the design principles and models governing these emerging biosocial and biopolitical interfaces that are intimately involved with scientific research? Who, what and how to regulate in such exchange of data? Are these interfaces just another symptom of the growing objectification of our identity and social relations by numerous online databases which suggest to us what to read, who to meet, what to eat and when to exercise (persuasive design and so called "captology")? ${ }^{16}$ Do they objectify human beings into the biopolitical subjects envisioned by Michel Foucault ${ }^{17}$ or do they create hybrid "quasi-subjects" and "quasiobjects" that are the ideal citizens of Bruno Latour's cosmopolitics? Are we creating conditions for more pervasive disciplinary control on the level of DNA? Will this new control segment and define the whole population in terms of DNA data that are viewed both as a resource and issue of management? Does this surge of various data offer the possibility for cosmopolitics, defined as "collective experiments", "progressive compositions" and "provisional assemblies", ${ }^{18}$ between various (social and material, human and non-human) actors?

I want to argue for both of these philosophical frameworks as important points of reference which will help us connect issues in policy and design. The rapid

Genomics, Society and Policy, Vol.6, No.1 (2010) ISSN: 1746-5354

(C) ESRC Genomics Network. 
convergence of biotech and web technologies in bionetworking is already involving design principles and strategies in the broader ethical, social and economic issues raised by these services. The interactions between the biological and the social, the material and the "data aspects" of our existence are bringing together issues of philosophy, policy and design. Bionetworking offers not only a rich material for discussing science, technology and society (STS) issues involved in consumer genomics but also a possibility of experimenting and using the design of these new services to test different views on biological citizenship and biosociality. The design of biosocial and biopolitical interfaces as a methodology for research in STS could allow us to understand whether and how human identities today are formed around predispositions to certain diseases, medical conditions, different molecules and cells. In short, identity is negotiated between different notions of the subject, the user and the human in philosophy and STS (biosocial and biopolitical subject), humancomputer interaction (HCI) (prosumer, produser) ${ }^{19}$ and personal genetic information services (PGI) (pre-symptomatic individual).

\section{Cui bono of bionetworking and methodological uncertainty}

The "cui bono" of these biosocial experiments and bionetworking interfaces is still rather unclear, both in terms of design and philosophy, which affects discussions on regulations and policy. We are left to wonder whether these interfaces actually serve any user needs and whether there is any value to citizen participation in scientific research based on these services. Given the risks involved in terms of privacy and the problematic validity and utility of the genetic data, who benefits from these services? Are we designing for individual users, or we are serving the biotech and pharmaceutical industries and their scientists who need more data for projects with unclear commercial interests? Are we designing for humans at all, or we are helping some form of "selfish" DNA optimise its conditions for reproduction via web 2.0 technologies?

Attempts to answer these questions in recent years have led to new methodologies and frameworks which are taking seriously the challenges of rapidly evolving connections between various actors in these novel services. Sandra Soo-Jin Lee and LaVera Crawley are using a combination of social networking analysis and ethnography to map the stakeholders, interests and actors involved in these services and networks. Their goal is to understand the dynamics of the evolving bionetworks in terms of the distribution of social capital, authority and influence:

A social network analysis could provide empirical data on the evolving impact of PGI on the health system in mapping whether and under what circumstances consumers share their information with their health care provider. Social network analysis offers an opportunity to discover the full range of communication of PGI and how it impacts social relationships that extend beyond those with physicians and health care providers. By identifying how PGI touches family, friends, community members and strangers, scholars may be better poised to identify and address the ethical and social implications of PGI. ${ }^{20}$

Aviad E. Raz's seminal text ${ }^{21}$ on the issue of "community genetics", however, discusses the alliances and connections built around certain DNA by using a case studies approach. The original (pre-online) forms of genetic and carrier testing used in 
communities with a higher risk of certain genetic conditions and in various patient groups had a clearer structure, function and goals, mainly related to genetic risk, than is the case today. While Raz mentions web forums and consumer services as mediums for community genetics in 2008 and 2009, he could not have predicted the sudden popularity of such services and the diverse forms of online bionetworking which we are starting to witness. His use of interviews, ethnographic observations and textual analysis from the field studies, which took place between 2001 and 2008, identified the different social actors and services that are part of the "networks of genetic testing, screening and counseling". ${ }^{22}$ The genetic communities he studied were either traditional, in terms of their ethnic and religious characterisation, or what he calls "ad hoc", referring to genetic alliances and patients' groups that are technologically savvy and aim to use new tools in their battle for funds, research and attention. ${ }^{23}$ In both of these cases, the policy issue is whether the field of community genetics should be a public health activity, a clinical programme, or a grassroots initiative, and whether and how to combine all three aspects.

The need for new methodologies in social networking analysis clearly shows that the diversity behind the new online services opens unexpected new questions that make the issue of policy more complex because it involves more actors and stakeholders. Online genetic services offer various functions, from personal genealogies and health reports to newer services which are more akin to a form of entertainment, while citizen science projects can be found online which are conducted by individuals who are not part of any patient group or community at a higher risk of a certain condition. New consumer genomic services have blurred the difference between public health activity, clinical programme and grassroots activity in the recent "clinical 2.0 trials" and citizen science projects. ${ }^{24}$ This rapid convergence between the web and genetic technologies is leading some researchers to avoid the whole issue of mapping actors and understanding the new networks and to concentrate on the philosophical issues of technological agency and political philosophy.

Marina Levina defines these novel forms of bionetworking interfaces as the most recent manifestation of the "social-networking culture which emphasises continuous and constant sharing of oneself with others". ${ }^{25}$ Bionetworking subjects, Levina argues, are just the most recent form of "networked subjectivity" and products of the "control society" that defines the present neoliberal condition. The STS notions of "biological citizenship" and "political economy of hope" ${ }^{26}$ are just forms of consumer behavior in a fully networked society operating within the "free labor" paradigm. In the networked society we are pushed to perform acts of citizenship by sharing information with others as part of exploring that interaction with strangers and searching for emergent patterns:

No longer beholden to the interests of the nation-state, citizenship in a control society is measured through participation in the network. As a product of social media and network subjectivity, citizen bioscience is fully aware of the value of information in control societies; its participants know that information makes the network function. Whereas biological citizens are reluctant to share their information, participants in citizen bioscience, trained through social-networking technologies and network subjectivity, are eager to do so. Their citizen's duty is to increase the capacity of the network .... Therefore, whereas biological citizenship operates 
through political economy of hope, citizen bioscience is embedded in the "free labor" economy of network society. ${ }^{27}$

Levina's provocative distinction between the "biological citizenship" operating through the "political economy of hope" and web 2.0 based "citizen bioscience" that is "embedded in the "free labor' economy of network society" summarises well the methodological uncertainties accompanying present discussions of bionetworking. While the original STS research on 'community genetics' and 'biological citizenship' defined policy as an issue of political philosophy and social sciences research, the networked and online character of the neoliberal economies and their new bionetworking services are pushing us to acknowledge technological agency and design as an important aspect of any future discussion. We need to connect policy with design research that is involved with emergent technologies on their material base and not only in terms of user research. Examples such as critical and speculative $\operatorname{design}^{28}$ offer models of how design can be used as a critical tool to define new questions and understand the interaction between various new actors. In this respect, issues of biopolitics and biosociality, which are discursive tools referring back to the interests and methods of Michel Foucault, can be combined with material practices and experiments closer to the Actor Network Theory paradigm of "heterogeneous networks or actors" and more normative concepts of "cosmopolitics".

\section{Connecting policy with design in bionetworking}

How to account for the pace with which these novel online applications are redefining the meaning of "biological citizenship" and exploring new forms of "genetic alliances and communities"? The agency of the technology involved in these novel gene-centric networks highlights the importance of design as a discipline and a research methodology. The challenge is not only to describe how these networks operate today, but also to discover how policy and design can participate in the bionetworks that will develop in the near future over mobile phones, iPads and other interfaces. How can bioethical and policy issues related to confidentiality, privacy, validity and the utility of DNA data be translated into design principles? How might issues of social capital, common property, access and accountability connect to current design practices related to democratisation of science ("Research 2.0", "Crowdsourcing" "30 etc.)?

The biosocial and biopolitical interfaces related to consumer genomics offer rich material for discussing the STS issues involved in biological citizenship and similar genetic communities, alliances and networks. Furthermore, they offer the possibility of experiments in the form of the design of new services that would test different views of biological citizenship and the varieties of relations and communities that can be constructed out of the molecular levels of our identity. We need to test different scenarios to understand how interfaces that will broaden the use of DNA data might serve various goals, from the more ethical (such as the relief of human suffering), to the more sinister (such as control and the commodification of human life). We need interfaces that will allow us to understand these new communities, their novel strategies centered on monitoring, crowdsourcing and interpreting biodata, and the systems of obligations and exchanges that are being generated. An important step in this direction is to understand not only the present state of the STS debate but also the material and technological agency which is part of the design process. 
Bionetworking operates on tricky ground, where the dignity of the human condition clashes with the science of human conditioning, and questions what it means to be human. We can describe these interfaces as actual design experiments with hybrid collectives and identities emerging in the networks of the objective and the subjective, human and non-human, social and biological agents. By reducing our identity to a part of our DNA that we share online, we are establishing new types of interactions that could have unforeseen consequences. In the case of genealogical services, we can even form whole new "global tribes" and extended families that did not evolve over time, but are a product of this game of chance and serendipity that relies on user data uploaded from around the globe. Complex and impersonal data, such as DNA, redefine and create new personal histories and influence our relations with other humans and the environment.

Bionetworking interfaces connect scientific facts with social and political structures and actors on a very personal level, redefining our identities and traditional institutions like the family. People sharing personal aspects of their "objective" identity, such as DNA or other biodata, connect online to redefine who their most valuable relations are, making their sense of belonging a game of chance. Together with the real-time data-logging of life indicators, such as temperature, heart rate, heart rhythm, and blood oxygen saturation, biodata can be used for different types of interactions from dating to games, from health services to genealogy, and different forms of collaborative entertainment around new utopian and dystopian communities.

We can imagine mobile applications enabling us to meet people with the same rhythm of heartbeat or similar DNA in the subway, so that we can create temporary, ad hoc relations with such "familiar strangers", resulting in a collective heartbeat in a certain part of a city. Dystopian and eugenic societies based on a particular understanding as to what sort of DNA or biodata are the pre-requisites for a peaceful and valuable community are also possible outcomes. The social and political consequences of organising our patterns of interaction on the basis of sharing our DNA or other biodata are already apparent in existing services, which contain hints of both utopian and dystopian versions of the future. People organised around certain genes on www.23andme.com and discussing their interaction with food, medicine and lifestyles efficiently experiment with such future communities, likely to be organised around "concerns" related to gene expression. Furthermore, the emerging concept of "Genopolitics" 31 and the citizen science projects organised around $\mathrm{it}^{32}$ are already identifying specific genes (related to serotonin and dopamine receptors) associated with political behaviors and attitudes which are triggered by the "right environment".

\section{HCI in the age of DNA}

Interfaces based on biological data call into question the basic divisions and assumptions of HCI about conscious human beings with intentions who use and communicate via unconscious agents (machines, computers) that are defined by processes and algorithms. The fundamental goal of HCI is to translate human intentions (mind, subjectivity) into computer algorithms or other objective processes in the outside world. ${ }^{33}$ This is difficult to maintain when human-technology interfaces are based on biodata, because such interfaces, besides translating and connecting humans with machines, also represent and objectify our subjectivity, calling into question our status as a subject. 
User-created profiles express human intentions, interests, values and needs that machines and computers can meet or even enhance. In contrast, biodata-based profiles, based on our genomes and other indicators, are created by science laboratories, not the individuals from whom the biodata is drawn, and it is not completely clear what these profiles express, or who or what they represent. They are a product of bioscience protocols, which are part of a large system of interests and processes (biocapital) ${ }^{34}$ related to different industries, rather than individuals, personal intentions and user needs. The SNP profile is not only a set of objective data about the molecular makeup of some individual. SNPs are also products and effects of the industry standards and protocols used in DNA sequencing, microarray analysis and different methodologies ${ }^{35}$. These profiles mirror the business interests of the pharmaceutical and biotech industries, which define bionetworking subjects as "presymptomatic" individuals who need products that will reduce the risk of developing various conditions.

Biological data have an ambiguous and unclear status in relation both to objective facts and social constructions, and their expression is often a strange amalgam of computer algorithms, scientific protocols, business interests, research intentions and social customs. As users of these data, we can never be completely certain whether we can trust their scientific, analytic and clinical validity and utility, because of the limits of DNA sequencing technologies. ${ }^{36}$ The influence of genes and SNPs on human behavior and needs is even less clear. For this reason, attempts to integrate such data into our personal and social relations and to create interactions based on biological data should be seen as experiments testing the borders between construction and fact, biological and social phenomena, private and public spheres. Thus, HCI in the age of DNA is not only about human and computer interaction, but more about the interaction between emerging technologies, society and politics. It is becoming a science of different forms of symbiosis between society and emergent technologies that goes beyond the simple interaction between individual users, or even groups of users, and their machines. We are forced to design and think on a level that is both more discrete and micro, and also more global and macro, in both the biological and social dimensions. The user and the human being are reduced to DNA, to their biological and psychological conditions, even neurotransmitters. The design is not only about a new type of interface that links user needs to some community and machines, but the design of new types of community that redefine the relationships between business, biotechnology and politics.

The increased possibilities of personal genomics, coupled with new models of social networking, data aggregation and visualisation, and up-and-coming ad hoc and wireless sensor networks for medical monitoring, is a testing ground for such future forms of symbiosis. The exercise of designing new forms of interaction between human biology (scientific facts like DNA), new media (discursive, cultural and media structures like the web 2.0 paradigm) and society (social micro and macro structures like family, community etc.) provides valuable material for discussing issues ranging from STS and philosophy of biopolitics to more practical issues related to environmental challenges and sustainability and the proposed framework of cosmopolitics 


\section{Bionetworking from biosociality and biopolitics to cosmopolitics}

Bionetworking interfaces already embody the STS concepts of "biosociality", 37 "biological citizenship, informational, digital bio-citizenship", 38 "therapeutic citizenship, "genetic citizenship, biocracy", "techno-social global assemblages", "global biological" 42 and other attempts to define the future forms of a society and individuals immersed in biotechnologies. These interfaces experiment with hybrid collectives and identities that are formed around a specific form of what actornetwork theory calls "heterogeneous networks of human and non-human actors" 43 , 44,45 and what STS genomic studies refers to as "genetic communities and alliances", 46

The inclusion of biological identity and health conditions in discussions of social interaction and modern citizenship is seen as a problematic but somehow necessary trend that is connected even to forms of resistance in the case of various patient groups (biosociality ${ }^{47},{ }^{48}$ ). Biosociality radicalises the paradoxes involved in the concept of biopower and biopolitics (Michel Foucault, ${ }^{49}$ Giorgio Agamben ${ }^{50}$ ). It reassumes the critiques of liberalism by reflecting on a politics that is merging with forms of management of the biological and private lives of citizens in terms of healthcare, conformity and consumerism. The "biopolitical" condition leads to the unprecedented homogenisation of society and biological "normalization", creating more efficient means of discipline and control that target more aspects both of society and of the individual. ${ }^{51}$ The discussion of biopolitics is a more recent version of the traditional critique of liberalism that views any reduction of the political to individual, social, economic and technological interests as a dangerous precedent which alienates humans and society from their real potential as historically defined and as a matter of culture rather than biology $52,53,54$. The convergence of biotechnology with the private lives of citizens (in terms of social networking) and our public, political and economic aspirations reopens the old debates with liberalism. The new bionetworks and biocommunities that use DNA to form relations and communities online are a good example of the reduction of the political and social to the biological and scientific. Biological identities, in the form of DNA, transform and challenge the relationship between the private and public, our biological and social lives, and what we define as subject, user and human. These interfaces make the interaction between society and emergent technologies visible. The coupling of social institutions and biological facts makes us reflect on the meaning of: being human in the age of biotechnology, being a subject in the age of biopolitics, and being a consumer and user in the age of biopolitical and biosocial services. In order to react to these challenges we need to connect design, policy and philosophy in forms of experiments rather than only discussions, we need to connect issues of biopolitics with design methodologies inspired by cosmopolitics.

\section{Bionetworking as interaction between quasi-subjects and quasi-objects}

DNA profiles define a user's identity in a way which is both "objective" and constructed. They represent the interests of the biotech industry and the scientific status of a particular set of DNA molecules, as much as the biological and idiosyncratic characteristics of different people. DNA profiles are hybrids and amalgams of social, biological and discursive forces and are products of complex networks between science, technology and society. Thus, users of biosocial and 
biopolitical interfaces are "quasi-subjects" defined by "quasi-objective" data: profiles based on biologically constructed data. ${ }^{55}$ Subjects are understood in terms of their DNA and become objects of various bureaucratic, medical and other systems and protocols. The semi-objective and semi-constructed properties of their DNA profiles connect the information about molecules with different aspects of individuals' social, private and public lives to form hybrid user identities and amalgams of social, political and scientific agents and forces.

These bionetworking interfaces connect scientific facts with social and political actors on a very personal level and affect our traditional institutions of family and community, including dating. People sharing very personal aspects of their "objective" identity, based on DNA or other biodata, connect online to redefine their most valuable relations and their sense of belonging through a simple game of chance. The "scientific" foundation and expert knowledge which define these DNA profiles are basically applied outside of their usual research context and serve social experiments with rather unclear goals. Social networking based on DNA profiles and other biodata in different biopolitical and biosocial interfaces defines a new paradigm of interaction: "quasi-objects" to "quasi-subjects" rather than humans to computers. These interfaces and services redefine the meaning of interactivity, which becomes less similar to the translation of human intentions into machine algorithms and more akin to a complex network between "quasi-objects" and "quasi-subjects". The goal of these interfaces is not the enhancement of the individual or group abilities and dynamics, but rather the enhancement of new symbiotic relations between human (personal, socially constructed, subjective) and non-human actors (DNA, databases, protocols, machines). Bionetworking creates hybrid networks and complex dependencies between newly defined quasi-subjective and objective entities that are in a process of exchanging their properties and forming new networks.

The hybrid networks of humans and non-humans and the symbiosis of quasi-subjects and quasi-objects revives and reverses the original concepts of real-time and interactive computing posited by J.C.R. Licklider ${ }^{56}$ or Douglas Engelbart. ${ }^{57}$ While Engelbart and Licklider envisioned man-computer symbiosis as the gradual approximation of machines to human minds and language, bionetworking questions the whole idea of human identity, integrity and control as something that is stable and given. Human identities are objectified into computable and manipulable codes and DNA information that make humans closer to machines. While Licklider envisioned machines that talk and think like humans and are potentially "alive" and even better than humans, the interfaces based on DNA and biodata give a new meaning to his original vision:

Man-computer symbiosis is probably not the ultimate paradigm for complex technological systems. It seems entirely possible that, in due course, electronic or chemical 'machines' will outdo the human brain in most of the functions we now consider exclusively within its province. ${ }^{58}$

Interactivity in the age of personal genomics and any subsequent objectification of human beings raises questions about the division between conscious humans and unconscious nature and between intentionality of humans that is socially and intersubjectively constructed and agency of things that is objectively given by chemical and other processes. 
Examples of hybrid networks that reflect some new form of symbiosis between humans (society) and technologies include the Donor Sibling Registry ${ }^{59}$ and its technologically-created families, and GenePartner ${ }^{60}$ "matching people by analyzing their DNA". The identities, relations and communities constructed on these websites with the help of quasi-subjective and quasi-objective profiles are often radical experiments rather than enhancements or even replacements of "normal" and common human institutions. For example, Donor Sibling Registry is a social networking site which connects donor-conceived individuals with their half-siblings and with the sperm and egg donors responsible for their conception. The website was founded in September 2000 and by November 2010 it connected almost 8,000 half-siblings (and/or donors) via the ID number of their biological donors. The total number of people registered in November 2010, including donors, parents and donor-conceived people, was more than 29,000 . This social networking creates non-traditional quasifamilies based on shared DNA and the combination of reproductive and web technologies. We are witnessing the emergence of "multi-nuclear" families defined by two and even more "centres" (single parents) and a strange polygamy in which many mothers have children that are half-siblings related to a single father, whose only parental action is to donate his sperm. They are made possible by the interaction between various "quasi-objects" and "quasi-subjects": sperm, social customs, family traditions, scientific data and technologies.

"Quasi-objects", such as DNA and other biodata that redefine our "quasi-subjective" profiles, change the meaning of being human, having a family, becoming a member of a society, and of being a user of such services and interfaces. They offer a model of interaction that can be described as a symbiotic experiment. On the one hand, these experiments create whole new ecologies rather than mere interfaces, and develop a stronger notion of what design means. On the other hand, from an STS perspective, they provide a setting for testing different views of biological citizenship and biosociality, and the related policy and ethical issues. We can experiment with these new forms of symbiosis by examining phenomena such as the personalisation of interfaces, networking, meeting and dating on social sites and even playing games over $\mathrm{DNA}^{61}$ in the future.

\section{Policy and design between biopolitics and cosmopolitics}

These just-mentioned scenarios of using DNA elevate the discussion on biopolitics and cosmopolitics to a new level. Social and biological identities are mobilised through technical innovations and creative design, fostering new forms of relationships, communities and networks in which it is difficult to distinguish between the social and the biological, the artificial and the natural, the discursively constructed and what is objectively and scientifically given. Bionetworking is a special phenomenon, in terms of its high level of dependence on an emerging scientific field (personal genomics) that involves individuals in its actual research (epigenetic), as well as in the sale of the products it develops (various SNPs and their interpretation). Since bionetworking's experiments require a large population of volunteers, it is an ideal opportunity to involve the public in science. However, there are also concerns, since no-one is completely certain what it will lead to and who will benefit from the data. Symbiotic experiments such as these that create new ecologies and dependencies are in some sense "post-human", since they open up the discussion of what it means to be human, what is considered to be an organism, and ultimately what life is. 
The use of biological data as a means of interaction and symbiosis questions the active and conscious control of users, and opens up space for serendipity as well as biological determinism. We are witnessing designs that objectify human subjects by making use of the molecular dimensions of their identity which they cannot control consciously. This could indicate some questionable intentions but also unprecedented possibilities. Interaction based on our biological identities is in open conflict with the phenomenological concept of embodiment and human activity being conscious and driven by the creation of meaning. On the one hand, this leads to a dystopian fear of biopolitical control and the reduction of humans to a collective and controlled animal species. On the other hand, however, this innovation opens up the possibility of achieving the cosmopolitical vision of experimental and provisional collectives at the boundary between human and non-human agents ${ }^{62}$.

The design of interfaces using DNA data is a biopolitical and cosmopolitical experiment, as it represents a challenge to the phenomenological approach to design that sees technologies as extensions of our meaning-creation activities ${ }^{63}$. The design of biosocial and biopolitical interfaces may not enhance the meaningfulness of human existence, and may instead create new problems and questions that are also the goal of any critical and speculative involvement with design. The age of personal genomics redefines our embodiment and identity, as well as the meaning of community, family and relationships. Such socio-technical and biopolitical experiments relate closely to the utopian and dystopian visions behind concepts such as "regenerative bioeconomy" 64 " "biological global as a biocultural and totalizing condition" "biological citizenship"66 "genetic citizenship" and "biocracy"67, "techno-social global assemblages" 68 , and "global experiment with modernity" and "everyday experiments" $" 69$ that discuss the future connected to our molecular and managed identities.

Human-computer interaction is making way for a more complex understanding of interaction involving symbiosis with different systems. We expect our technologies to help us understand and manage the different limits of our biological, social and political existences, rather than support the narrow techno-optimist forms of enhancement and extension. For this reason, designs in this "post-interactive" era prefer monitoring, visualising, reminding and persuading as the main functions of the new tools and applications that are working with large numbers of human and nonhuman actors. The traditional problems of ergonomics, which focused on enhancing users' cognitive abilities with better graphical user interfaces or user experiences through interactive or participatory design, are being subsumed by more complex problems that involve new agents and hybrid and semi-objects and subjects. Almost every design problem today involves aspects of biology, society, politics, and geography, and the solutions often affect whole ecosystems, habitats and institutions, instead of just a group of users. Users who were marginalised or ignored, as well as entire ecosystems and institutions, become active participants in this design process and influence its outcomes.

\section{Conclusion}

Connecting policy and design via bionetworking and biologging could serve as a methodology for addressing and discussing biopolitical and cosmopolitical issues in today's technological society. Biopolitical and biosocial interfaces have the potential

Genomics, Society and Policy, Vol.6, No.1 (2010) ISSN: 1746-5354

(C) ESRC Genomics Network. 
to become citizen-science interfaces and projects, and to support the science-society cooperation and interaction which Bruno Latour envisioned with his concept of cosmopolitics. However, they also threaten our traditions and values and could lead to new forms of control and biopolitics. These interfaces represent new forms of symbiosis and networks between human and non-human agents, between quasisubjects and quasi-objects, and it is difficult to predict and decide where is the line that we should not cross. It is possible that we have already created dangerous precedents that will result in eugenics-style experiments, with future states and communities built around genetically compatible people. Bionetworking interfaces and design offer an alternative space for evaluating different scenarios and versions of our future society. In this technosocial process, we are experimenting with new types of local and global awareness by creating different identities and communities in the contexts, not of states, but of our homes, neighborhoods, cities, countries or the entire planet and the biological habitat. The technosociety is a plural and hybrid collective, and a complex and emergent network involving new kinds of human and non-human agents as active participants.

\footnotetext{
${ }^{1}$ National University of Singapore. denisa@nus.edu.sg

$2 \mathrm{http}: / /$ www.genepartner.com

3 http://www.donorsiblingregistry.com

4 http://www.23andme.com

5 http://quantifiedself.com/

6 http://www.diygenomics.org

7 J. Sequeiros and B. Guimarães. Definitions of Genetic Testing.
} http://www.eurogentest.org/web/files/public/unit3/DefinitionsGeneticTesting-3rdDraf18Jan07.pdf

8 FamilyTreeDNA http://www.familytreedna.com/ and MyRedHairGene http://www.myredhairgene.com/

9 E. Paulos and E. Goodman. The Familiar Stranger: Anxiety, Comfort, and Play in Public Places. In: Proc. Human Factors in Computing Systems (CHI 2004), ACM Press, 2004, 223-230.

${ }^{10}$ N. Eagle and A Pentland, Social Serendipity: Mobilizing Social Software, IEEE Pervasive Computing 2005; 4 (2): 28-34. Doi:10.1109/MPRV.2005.37

${ }^{11} \mathrm{~S}$. Milgram. 1977. The Individual in a Social World : Essays and Experiments. Reading, Mass. Addison-Wesley.

${ }^{12}$ E. Goffman. 1967. Interaction Ritual. Essays in Face-to-Face Interaction. Chicago. Aldine.

13 A. Kittur, Ed H. Chi, and Bongwon Suh. 2008. Crowdsourcing user studies with Mechanical Turk. In Proceeding of the twenty-sixth annual SIGCHI conference on Human factors in computing systems (CHI '08). ACM, New York, NY, USA, 453-456. DOI=10.1145/1357054.1357127 http://doi.acm.org/10.1145/1357054.1357127

14 A. Bruns. 2007. Produsage. In Proceedings of the 6th ACM SIGCHI conference on creativity \& cognition (C\&C '07). ACM, New York, NY, USA, 99-106. DOI=10.1145/1254960.1254975 http://doi.acm.org/10.1145/1254960.1254975

15 F. Kensing and J. Blomberg. Participatory Design: Issues and Concerns. Comput. Supported Coop. Work 1998; 7 (3-4): 167-185. DOI=10.1023/A:1008689307411 http://dx.doi.org/10.1023/A:1008689307411

16 B.J. Fogg. 2003. Persuasive technology: using computers to change what we think and do. Amsterdam, Boston. Morgan Kaufmann.

${ }^{17}$ M. Foucault and M. Senellart. 1978-9. The birth of biopolitics : lectures at the College de France. Basingstoke; New York. Palgrave Macmillan.

18 B. Latour, 1993. We Have Never Been Modern. Cambridge, Mass. Harvard University Press.

19 A. Toffler, 1980. The Third Wave. NYC. Bantam Books

20 S. S-J. Lee and L. Crawley. Research 2.0: Social Networking and Direct-To-Consumer (DTC) Genomics The American Journal of Bioethics 2009; 9(6): 35-34. 
http://www.informaworld.com/10.1080/15265160902874452

21 A.E. Raz. 2009. Community genetics and genetic alliances: Eugenics, carrier testing and networks of risk. London, New York. Routledge.

${ }^{22}$ Ibid., p.28.

23 Ibid., p.29.

${ }^{24}$ Genomera Citizen Science Study FAQ. http://blog.genomera.com/citizen-science-study-faq; A. Malorye. Can Web 2.0 Reboot Clinical Trials? Nat Biotech 2009; 27(10): 895-902.

${ }^{25}$ M. Levina, Googling your genes: personal genomics and the discourse of citizen bioscience in the network age. Jcom 2010; 9(1) A06: 1.

${ }^{26}$ Ibid., p.5.

${ }^{27}$ Ibid., p.7.

${ }^{28}$ A. Dunne and F. Raby. 2001. Design Noir: The Secret Life of Electronic Objects. Basel. Basel. Birkhäuser.

${ }^{29}$ D. Rathi. and L. Given. 2010. Research 2.0: A Framework for Qualitative and Quantitative Research in Web 2.0 Environments. In Proceedings of the 2010 43rd Hawaii International Conference on System Sciences (HICSS '10). IEEE Computer Society, Washington, DC, USA, 1-10.

DOI=10.1109/HICSS.2010.317. http://dx.doi.org/10.1109/HICSS.2010.317

${ }^{30}$ D. Brabham. Crowdsourcing as a Model for Problem Solving. Convergence: The International Journal of Research into New Media Technologies 2008; 14: 75-90.

31 J.H. Fowler and D. Schreiber. Biology, Politics, and the Emerging Science of Human Nature. Science 2008; 322: 912-914.

32 "Behavioral Studies", part of the DIYgenomics website http://diygenomics.pbworks.com/w/page/23041784/FrontPage, where we can find citizen science projects such as 'Apply Correlated Genotypes in Friendship Networks study to peer cohort (James Fowler, UCSD)' and 'Investigate dopamine transmitter COMT's purported linkage to the ability to resolve conflict (Posner, Phys Life Rev 2009, paper)'.

33 B. Myers. A Brief History of Human-Computer Interaction Technology. Interactions 1998; 5 (2).

34 R. Sunder. 2006. Biocapital: The Constitution of Postgenomic Life. Durham. Duke University Press.

35 S. Gibbon and C. Novas. 2008. Biosocialities, Genetics and the Social Sciences: Making Biologies and Identities. London; New York. Routledge.

${ }^{36}$ K. Ovesen and U. Matthiesen. 2009. DNA Fingerprinting,Sequencing, and Chips. Hauppage, New York. Nova Science Publishers.

37 P. Rabinow. 1996. Essays on the Anthropology of Reason. Princeton. Princeton University Press. 'Artificiality and Enlightenment' 99-103.

38 N. Rose and C. Novas. 2004. Biological Citizenship. In Global Assemblages: Technology, Politics, and Ethics as Anthropological Problems. A. Ong and S.J. Collier, eds. Oxford. Blackwell Publishing; 439-463.

39 V-K. Nguyen. 2004. Antiretroviral Globalism, Biopolitics, and Therapeutic Citizenship. In Global Assemblages: Technology, Politics, and Ethics as Anthropological Problems. A. Ong and S.J. Collier, eds. Oxford. Blackwell Publishing: 124-144.

40 D.J. Haraway. 2008. When Species Meet. Minneapolis. University of Minnesota Press.

41 S. Collier. and A. Ong. 2004. Introduction. In Global Assemblages: Technology, Politics, and Ethics as Anthropological Problems. A. Ong and S.J. Collier, eds. Oxford. Blackwell Publishing: 3- 22.

42 S. Franklin. 2004. Stem Cells R Us: Emergent life forms and the global biologica. In Global Assemblages: Technology, Politics, and Ethics as Anthropological Problems. A. Ong and S.J. Collier, eds. Oxford. Blackwell Publishing: 59- 79.

${ }^{43}$ B. Latour.2005. Reassembling the social: an introduction to actor-network-theory. Oxford; New York. Oxford University Press.

${ }^{44}$ M. Callon. 1986. The sociology of an actor-network: The case of the electric vehicle. In Mapping the dynamics of science and technology: Sociology of science in the real world. M. Callon, J. Law and A. Rip, eds. Basingstoke. Macmillan: $19-24$.

45 J. Law and J. Hassard, eds. 1999. Actor Network Theory and After. Oxford; Malden MA. Blackwell/Sociological Review.

${ }^{46}$ Raz, op. cit, note 20.

47 P. Rabinow. 2008. Anthropos Today : Reflections on Modern Equipment. Princeton NJ; Oxford. Princeton University Press.

${ }^{48}$ Gibbon and Novas, op. cit. note 34. 
${ }^{49}$ M. Foucault, M. Bertani, A. Fontana, F. Ewald and D. Macey. 2003. Society must be defended: Lectures at the Collège de France 1975-76. New York. Picador.

${ }^{50}$ G. Agamben. 1993. The Coming Community. Minneapolis. University of Minnesota Press.

${ }^{51}$ M. Foucault. 2009. Security, Territory, Population: Lectures at the College de France 1977-1978. New York. Picador.

${ }^{52}$ G.W.F. Hegel. 1991. Elements of the Philosophy of Right. Cambridge; New York. Cambridge University Press.

${ }^{53}$ C. Schmitt. 2007. The Concept of the Political. Chicago. University of Chicago Press.

${ }^{54}$ H. Arendt. 1977. Between Past and Future: Eight Exercises in Political Thought. New York. Penguin Books.

${ }^{55}$ Latour, op.cit. note 18.

56 J.C.R Licklider. Man-Computer Communication. Annual Review of Information Science and Technology 1968; 3: 201-240.

${ }^{57}$ D. C. Engelbart. 1962. Augmenting Human Intellect: A Conceptual Framework. Stanford Research Institute Summary Report on Contract AF 49(638) - 1024.

${ }^{58}$ Licklider, op. cit. note 55.

${ }^{59}$ Donor Sibling Registry, op.cit. note 3.

${ }^{60}$ GenePartner, op.cit. note 2.

${ }^{61}$ P. Vanouse. The Relative Velocity Inscription Device, 2002 http://www.contrib.andrew.cmu.edu/ pv28/rvid.html

${ }^{62}$ B. Latour. 2004. Politics of Nature: How to Bring the Sciences Into Democracy. Cambridge, Mass. Harvard University Press.

${ }^{63}$ P. Dourish. 2001. Where The Action Is: The Foundations of Embodied Interaction. Cambridge, Mass. MIT Press.

${ }^{64}$ C. Waldby and R. Mitchell. 2006. Tissue Economies: Blood, Organs and Cell Lines in Late Capitalism. Durham NC. Duke University Press.

${ }_{65}$ S. Franklin and M.M. Lock. 2003. Remaking Life and Death: Toward an Anthropology of the Biosciences. , Santa Fe. School of American Research Press.

${ }^{66}$ N. Rose. 2006. The Politics of Life Itself: Biomedicine, Power and Subjectivity in the Twenty-first Century. Princeton NJ. Princeton University Press.

${ }^{67}$ Haraway, op.cit. note 39 .

${ }^{68}$ Collier. and Ong, op.cit. note 40.

${ }^{69}$ U. Beck, A. Giddens and S. Lash. 1994. Reflexive Modernization: Politics, Tradition and Aesthetics in the Modern Social Order. Stanford CA. Stanford University Press: 56-109. 